\title{
First detection of a viral agent causing disease in farmed sturgeon in Russia
}

\author{
Igor S. Shchelkunov ${ }^{1, *}$, Tatiana I. Shchelkunova ${ }^{1}$, Artyem I. Shchelkunov ${ }^{2}$, \\ Yulia P. Kolbassova ${ }^{2}$, Lubov V. Didenko ${ }^{3}$, Albert P. Bykovsky ${ }^{3}$ \\ ${ }^{1}$ All Russia Research Institute for Veterinary Virology and Microbiology, Pokrov 601120, Russia \\ ${ }^{2}$ All Russia Research Institute for Freshwater Fisheries, Rybnoe 141821, Russia \\ ${ }^{3}$ N. F. Gamaleya Research Institute for Epidemiology and Microbiology, 18 Gamaleya St., Moscow 123098, Russia
}

\begin{abstract}
A virus was isolated from Siberian sturgeon Acipenser baeri and bester (beluga Huso huso $\times$ sterlet $A$. ruthenus hybrid) fingerlings in SSO-2, SSF-2 and WSSK-1 cell lines during an acute epizootic on a large fish farm producing fertilised sturgeon eggs and fry. Transmission electron microscopic examination of samples from both inoculated cell cultures and skin of affected fish revealed viral particles with a herpesvirus-like morphology. The etiological role of the Siberian sturgeon herpesvirus (SbSHV) was confirmed by fulfilment of Rivers' postulates. Experimental immersion of healthy Siberian sturgeon fingerlings in a suspension of SbSHV resulted in $100 \%$ mortality with signs of focal epidermal hyperplasia, skin necrosis and multiple skin haemorrhages. While infecting different organs and tissues, the virus showed clear integumentary tropism. Carp fry and rainbow trout fingerlings were neither susceptible to the virus nor did they transmit it to healthy Siberian sturgeon.
\end{abstract}

KEY WORDS: Siberian sturgeon · Herpesvirus · Pathogenicity

\section{INTRODUCTION}

Sturgeon farming has become an important and rapidly expanding sector of aquaculture worldwide. This applies to both the growing of fry and fingerlings for restocking natural reservoirs as well as the production of table sized fish and caviar for the market.

As in the culture of other fish species, diseases are a principal limiting factor in sturgeon farming. Among them, viral diseases often cause major damage to the industry. To date, around 10 specific viruses have been found in sturgeons. Almost all of them were discovered in sturgeons native to North America, both in the USA and Canada, as well as in Europe (Italy), where these fish species were introduced (LaPatra et al. 2001, Raverty et al. 2003, Kelley et al. 2005). The only virus found in non-American sturgeon species was an iridovirus-like agent visualised by electron microscopy in diseased juvenile Russian sturgeon Acipenser guel- denstaedtii in a Belgian fish farm (Adkison et al. 1998). Viruses specific to sturgeons include adenoviruses, papovaviruses, iridoviruses and herpesviruses (Kelley et al. 2005). Of these, the white sturgeon A. transmontanus iridovirus (WSIV) and white sturgeon herpesvirus type 2 (WSHV-2, later renamed to Acipenserid herpesvirus 2, AciHV-2) are economically the most significant pathogens, causing up to $95 \%$ mortality in cultured young sturgeon (Watson et al. 1995, Georgiadis et al. 2001, Kelley et al. 2005).

Until recently, the world's largest stocks of wild sturgeon have been concentrated in Russia. For decades, extensive national programmes on restoration of natural sturgeon stocks were being carried out in the country. However, with regard to sturgeon pathogens, only parasites have been studied comprehensively (Kazarnikova 2007), while little attention has been paid to infectious diseases, particularly viral infections. Here we report on the first sturgeon virus found in Russia. 
In the spring of 2006, an acute disease outbreak occurred in a large warm water sturgeon hatchery situated in Tver Province in the European part of Russia. The outbreak resulted in a mass mortality of fry and fingerlings, with Siberian sturgeon Acipenser baeri being the most susceptible fish among several sturgeon species cultured there. Up to $100 \%$ mortality was registered in some fish lots.

The disease developed at a water temperature range of 14 to $19^{\circ} \mathrm{C}$. Affected fish were lethargic, consumed no food, had a lighter colour than normal and remained at the rearing tank bottom. Multiple haemorrhages on the ventral part of the rostrum, around the mouth and on the abdominal and lateral body surfaces were the most prominent clinical signs. In moribund fish, the liver was extremely pale, almost white. Saprolegnia sp. and myxobacteria were also found in the skin and gill tissues of many of the diseased fish. However, treatments against these secondary invaders did not result in substantial improvement of fish condition. After parasites and bacteria were excluded as possible causes of the disease, affected tissues from diseased fish were sampled for virological examination.

\section{MATERIALS AND METHODS}

Virus isolation. For virological examinations, samples of affected mouth and gill tissues were collected from 17 fingerling Lena sturgeons (a race of Siberian sturgeon) aged 1.5 to 4 mo old, and from 2 fingerling 3 mo old besters (great sturgeon Huso huso $\times$ sterlet Acipenser ruthenus hybrids) each with a body weight between 3 and $25 \mathrm{~g}$. The collected samples were pooled from 2 to 7 fish and transported to the laboratory in chilled $\left(2\right.$ to $\left.4^{\circ} \mathrm{C}\right)$ condition in Eagle's minimal essential medium (MEM) supplemented with 10\% foetal calf serum (FCS; Life Technologies), penicillin (300 I.U. ml $l^{-1}$ ) and streptomycin $\left(300 \mu \mathrm{g} \mathrm{ml}^{-1}\right)$. The time interval between sampling the fish tissues and their processing in the laboratory did not exceed $24 \mathrm{~h}$.

Samples were homogenised and a $10 \%(\mathrm{w} / \mathrm{v})$ suspension was prepared in Eagle's MEM medium with the above-mentioned antibiotics, and this was centrifuged for $30 \mathrm{~min}$ at $1560 \times \mathrm{g}$. The supernatant was used for inoculation of 2 permanent cell lines established from pooled internal organs (spleen, kidney, liver) or fins of Siberian sturgeon (SSO-2 and SSF-2, respectively) (Shchelkunova et al. 2006) and WSSK-1 cell line of skin (courtesy of Prof. R. P. Hedrick, California State University, Davis, CA) from the white sturgeon Acipenser transmontanus (Hedrick et al. 1991). The cells were inoculated with 4 consecutive 10 -fold dilutions of the tissue sample supernatant prepared in the medium 199 (Morgan et al. 1950). Inoculations were done simultaneously with seeding cells in 96well culture plates (Nunc) in growth medium consisting of medium 199 (for SSO-2 and SSF-2 cells) or Eagle's MEM medium (for WSSK-1 cells) supplemented with $10 \%(\mathrm{v} / \mathrm{v})$ FCS and $40 \mu \mathrm{g} \mathrm{ml}^{-1}$ gentamycin. Inoculated cells were incubated for $1 \mathrm{~d}$ at $19^{\circ} \mathrm{C}$ to allow the cultures to reach approximately $100 \%$ confluency, then transferred to $15^{\circ} \mathrm{C}$ and examined daily by light microscopy for the appearance of viral cytopathic effect (CPE). At completion of CPE development, the viral titre was calculated according to Reed \& Muench (1938).

Electron microscopy. SSF-2 cells with extensive CPE were fixed with formaldehyde-glutaraldehyde (Ito \& Karnovsky 1968), postfixed in $1 \% \mathrm{OsO}_{4}$, dehydrated through a graded alcohol series and embedded in acrylic resin LR White (Sigma). Ultrathin sections prepared were stained with uranyl acetate and lead citrate (Reynolds 1963) and examined using a JEM 100B electron microscope (JEOL) at 20000 to $40000 \times$ magnification. Essentially the same technique was used for examination of affected skin samples from experimentally infected fingerlings of Siberian sturgeon.

Infection trials. To verify the disease etiology, an artificially induced infection was performed: 2 mo old healthy Siberian sturgeon fingerlings with mean body weight of approximately $12.5 \mathrm{~g}$ were infected with the virus by bath immersion. These sturgeons were purchased as fertilised eggs from the BIOS sturgeon hatchery, Astrakhan Province, Russia, and grown under controlled laboratory conditions. No viruses were found in these fish sampled for virological examinations before the trial and tested by cell culture inoculation as described above. Fish $(\mathrm{n}=48)$ were placed in $2 \mathrm{l}$ of static aerated water $\left(15\right.$ to $\left.17^{\circ} \mathrm{C}\right)$, to which the viral strain SK1/0406 isolated from integumentary fish tissues (from the fifth passage in SSO-2 cells) was added to a final concentration of $10^{4.7}$ tissue culture infective dose $50 \%\left(\mathrm{TCID}_{50}\right) \mathrm{ml}^{-1}$. After exposure for $1 \mathrm{~h}$, the fish were moved to a $90 \mathrm{l}$ aquarium with flowthrough aerated water at 15 to $17^{\circ} \mathrm{C}$, in which they were further held and regularly fed with commercial pelleted feed. Fifty control fish were mock-infected in a similar way using uninfected SSO-2 cell culture medium and kept under the same conditions. Daily, clinical signs and mortalities were scored and freshly dead fish sampled for virus re-isolation. At $14 \mathrm{~d}$ post exposure, the last infected sturgeon died and the experiment was terminated.

A similar method was used for the experimental infection of 2 yr old Siberian sturgeon $(\mathrm{n}=11$; body weight of 300 to $400 \mathrm{~g}$ ) except that for infection the fish were placed in $40 \mathrm{l}$ of $15^{\circ} \mathrm{C}$ water in a $250 \mathrm{ltank}$, and the virus concentration used was $10^{3.85} \mathrm{TCID}_{50} \mathrm{ml}^{-1}$ water. After exposure to the virus for $1 \mathrm{~h}$, about three- 
fourths of the volume of the virus suspension was discharged before the water flow (at 14 to $16^{\circ} \mathrm{C}$ ) to the tank with the fish was restored. Negative control fish were mock infected with uninfected SSO-2 cell culture medium and kept in similar conditions in a different tank.

Samples of skin mucus, skin, fin and mouth tissues, gill, gill opercula, barbel, brain, liver, kidney, spleen, hind gut contents and abdominal exudate of experimentally infected moribund fishes were processed for virological examination as described above.

The pathogenicity of the isolated virus to carp Cyprinus carpio fry and rainbow trout Oncorhynchus mykiss fingerlings was also tested. Firstly, 100 carp fry (mean body weight of approximately $300 \mathrm{mg}$ ) kept at 15 to $17^{\circ} \mathrm{C}$ were infected with the virus by bath immersion $\left(10^{4.68} \mathrm{TCID}_{50} \mathrm{ml}^{-1}\right.$ water for $\left.1 \mathrm{~h}\right)$. The carp were then transferred to a 901 aquarium with flow-through, aerated water of the same temperature and regularly fed commercial pelleted feed. At 13 d post immersion, 9 healthy naïve fingerlings of Siberian sturgeon of approximately $12.5 \mathrm{~g}$ were placed in a different aquarium supplied with the outlet water discharged from the aquarium with the carp fry. After $4 d, 32$ carp fry were taken from the first aquarium and processed as whole fish in pools of 2 to 3 individuals for virological examination on the SSO-2 cell line as described above. Thirty-five days after the beginning of the experiment, caudal fins from the remaining 68 carp fry were processed in pools of 6 to 7 fish and examined in the same way.

Secondly, for virus infection, 100 healthy 6 mo old rainbow trout Oncorhynchus mykiss fingerlings (body weight 5 to $7 \mathrm{~g}$ ) were placed for $5 \mathrm{~h}$ exposure in a $90 \mathrm{l}$ aquarium supplied with the outlet water from another 901 aquarium containing 2 moribund 3 mo old fingerlings (body weight 15 to $20 \mathrm{~g}$ ) of Siberian sturgeon Acipenser baeri infected by immersion $20 \mathrm{~d}$ previously at 15 to $16.5^{\circ} \mathrm{C}$ and displaying typical signs of disease. In addition, after the exposure, the rainbow trout were held for $4 \mathrm{~h}$ at 14 to $14.5^{\circ} \mathrm{C}$ in an aerated $0.1 \%$ suspension of affected tissue homogenate in water, which was prepared as described above from pooled mouth, fins, skin and mucus of the same 2 moribund Siberian sturgeon fingerlings. This suspension contained approximately $10^{3} \mathrm{TCID}_{50}$ virus $\mathrm{ml}^{-1}$. The fish were then kept in a $90 \mathrm{l}$ flow-through aquarium with water temperature of 14 to $15^{\circ} \mathrm{C}$ and regular feeding of pelleted trout feed. After 7 d, 6 healthy Siberian sturgeon fingerlings were added to the virus-exposed rainbow trout for cohabitation. Twenty-six days after the beginning of the experiment, pectoral and abdominal fins from 50 rainbow trout, in pools of 5 fish each, were sampled for virus isolation on SSO-2 cells as described above followed by the remaining 50 rainbow trout $8 \mathrm{~d}$ later.

\section{RESULTS}

Virus isolation. A cytopathogenic agent was isolated in inoculated sturgeon cell lines from both diseased Siberian (isolates SK1/0406 and SK2/0506) and bester (isolate BK/0506) sturgeon fingerlings. The first signs of CPE appeared as focal destruction of the cell monolayer at $3 \mathrm{~d}$ post inoculation (dpi) in cultures of all 3 cell lines, which received 2 initial dilutions of tissue samples, and 2 to 9 d later, complete CPE involving the entire monolayer was evident. This process required 7 to $10 \mathrm{~d}$ more in cell cultures inoculated with the final sample dilutions. In general, cell rounding and detachment were seen, but the CPE varied in details in different cell lines. In the SSO-2 cell line, the virus-infected cells tended to aggregate along the growth axes of the fibroblast bunches. Clusters of dark round and picnotic WSSK-1 cells connected to each other by long and thin cell branches. A prominent feature of CPE in SSF-2 cells was the development of globoid giant cells. The CPE was consistently reproduced in subsequent passages of the samples in cell culture, thus indicating the presence of a cytopathic agent (Fig. 1). The titre of the isolated agent in fish tissues varied from $10^{5.9}$ to higher than $10^{7.1}$ TCID $_{50} \mathrm{~g}^{-1}$.

Virus morphogenesis. Ultrathin sections of virusinoculated SSF-2 cells were examined by transmission electron microscopy (TEM) and showed aggregates of virus particles. In the cell nuclei, empty icosahedral capsids of about 100 to $110 \mathrm{~nm}$ in diameter and capsids with concentrically located electron-opaque rings (possibly early nucleoid or polyamine protein structures) as well as full-packaged electron-dense nucleocapsids were found. The latter were often situated close to the nuclear membrane. Naked nucleocapsids were also numerous in the cell cytoplasm and within the intercellular space, where mature enveloped virions of 200 to $250 \mathrm{~nm}$ with an electron-dense tegument under the envelope were also present (Fig. 2). Primary nucleocapsid envelopment by virus budding through the inner nuclear lamina could be occasionally seen. At the final stages of virus development, extensive vacuolisation of cell cytoplasm was observed. Based upon the morphogenesis features, the virus was provisionally classified as a member of the order Herpesvirales, family Alloherpesviridae (Waltzek et al. 2006, Davison et al. 2009), and named Siberian sturgeon herpesvirus (SbSHV).

Experimental infections of young Siberian sturgeon with SbSHV. First signs of disease in experimentally infected sturgeon fingerlings occurred at about $6 \mathrm{~d}$ dpi. At 9 dpi, mortality began and approached 100\% 5 d later (Fig. 3). Moribund fish displayed clinical signs typical of those found in diseased sturgeons during the outbreak on the affected fish farm. In the con- 

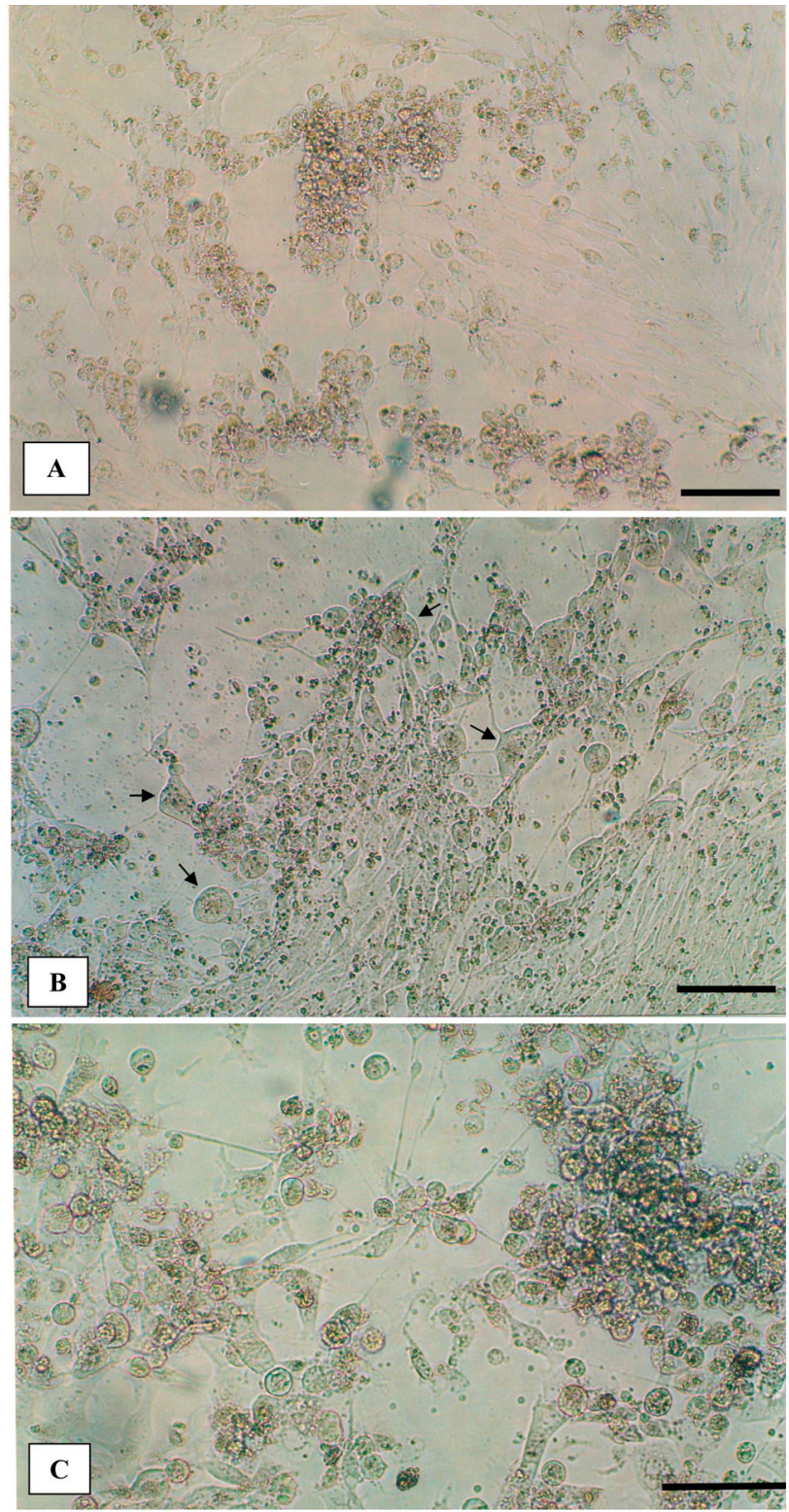

Fig. 1. Acipenser baeri. Cytopathic effect of Siberian sturgeon herpesvirus (SbSHV) in (A) SSO-2, (B) SSF-2 and (C) WSSK-1 cells at $8 \mathrm{~d}$ post inoculation at $15^{\circ} \mathrm{C}$. Unstained preparations. Note globoid giant cells in virus inoculated SSF-2 cell culture (arrows in B). Scale bars $=100 \mu \mathrm{m}$

trol group, 2 fish died with non-specific signs of tympania as determined upon necropsy. On Day 13 post infection, 3 healthy fish from the control group were added for cohabitation with the last moribund sturgeon, which remained in the test group. These healthy fish also became ill and died within 12 to $18 \mathrm{~d}$ post cohabitation.

The following observations were recorded after experimentally infecting the fish. The first signs of disease, revealed in infected fish at 6 dpi, were lethargy

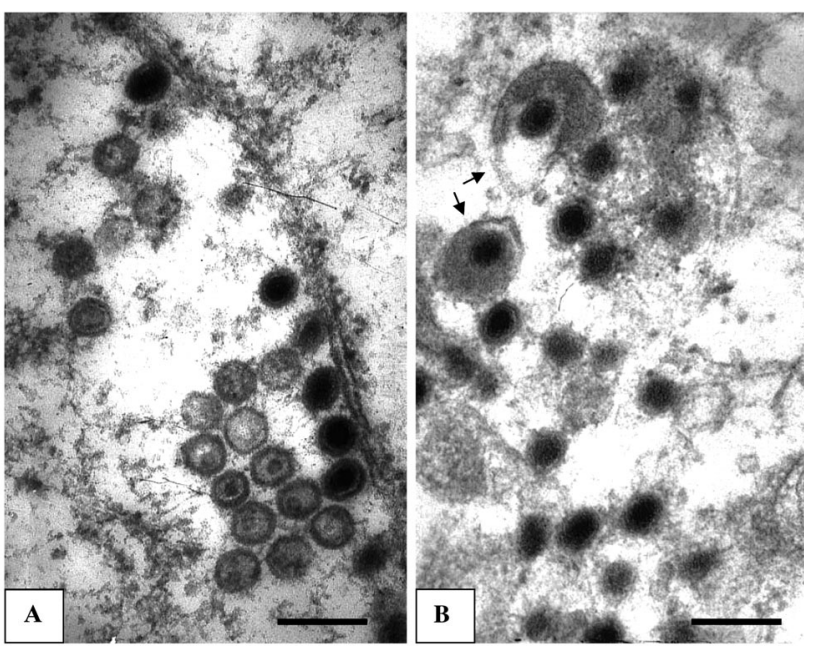

Fig. 2. Acipenser baeri. Transmission electron micrographs of (A) Siberian sturgeon herpesvirus (SbSHV) nucleocapsids from the nucleus and (B) enveloped virus particles (arrows) from intercellular space of infected SSF-2 cells. Scale bars $=200 \mathrm{~nm}$

and anorexia. In contrast to constantly moving healthy fish, the ill fish remained motionless on the aquarium bottom, breathing with increased effort and frequency. They became progressively more emaciated and pale. The pose of affected fish was characteristic: the caudal trunk extended upwards, causing the animal to 'stand' on its head and pectoral fins. Diseased individuals gradually resumed swimming a few days later, although their movements were restless and chaotic and involved periods of dorsal recumbence on the

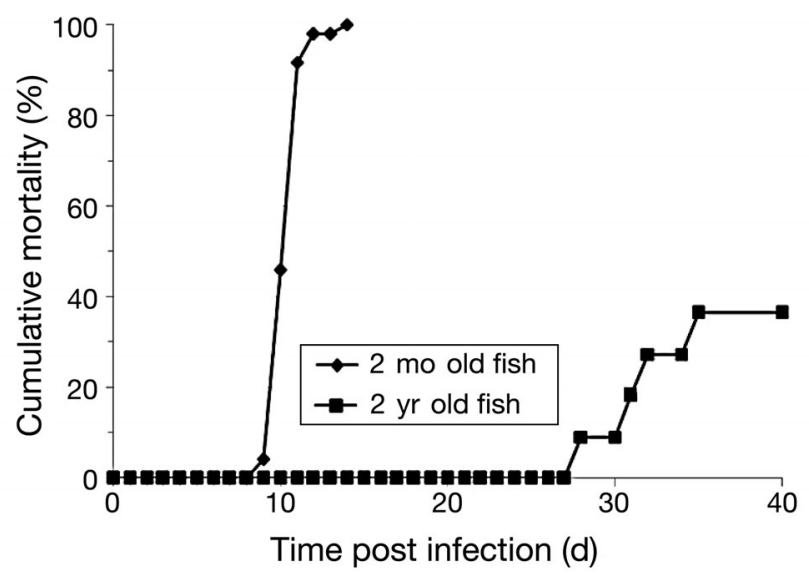

Fig. 3. Acipenser baeri. Mortality dynamics in juvenile Siberian sturgeon after immersion for $1 \mathrm{~h}$ with Siberian sturgeon herpesvirus (SbSHV) at the 5 th in vitro passage $\left(10^{4.7} \mathrm{TCID}_{50}\right.$ $\mathrm{ml}^{-1}$ water, 2 mo old fish, $\mathrm{n}=48$ ) or at the 13 th in vitro passage $\left(10^{3.85} \mathrm{TCID}_{50} \mathrm{ml}^{-1}\right.$ water, $2 \mathrm{yr}$ old fish, $\left.\mathrm{n}=11\right) \mathrm{kept}$ at 15 to $17^{\circ} \mathrm{C}$. No specific mortality was observed in the control fish groups exposed to uninfected SSO-2 cell culture fluid in a similar way 
aquarium bottom with frequent and shallow respiration. By 10 to $11 \mathrm{dpi}$, smoky-blue semi-translucent plaques rising over the skin and measuring from 1 to $4 \mathrm{~mm}$ in diameter appeared on different parts of the body (Fig. 4A). While resembling accumulations of skin mucus, these outgrowths were difficult to remove with a scalpel, suggesting that they were plaques of hyperplastic epidermis. Upon further gross examination of virus-infected fish, fin necrosis became evident at this stage of disease, starting from the distal ends. Also the tips of the gill filaments became pale. Under close examination of the diseased fish immersed in water, focal necrotic areas of the skin could be observed at 11 to $12 \mathrm{dpi}$, which were the result of proliferating epidermal plaque degeneration. Such necrotic areas of skin usually became infected with Saprolegnia or myxobacteria. In moribund fish, the anus was inflamed and swollen. One to $2 \mathrm{~d}$ prior to death, hyperemic areas and multiple petechiae appeared on the fish skin. These were numerous on lateral parts of the body, abdomen, and caudal trunk, at fin bases, below the eyes, and in the gills. However, the ventral part of the rostrum and particularly the mouth were most heavily affected.

Upon necropsy, general paleness of internal organs was evident, with the liver almost white in colour. The alimentary tract was usually free of food and the hind gut was sometimes inflamed and filled with pseudo-

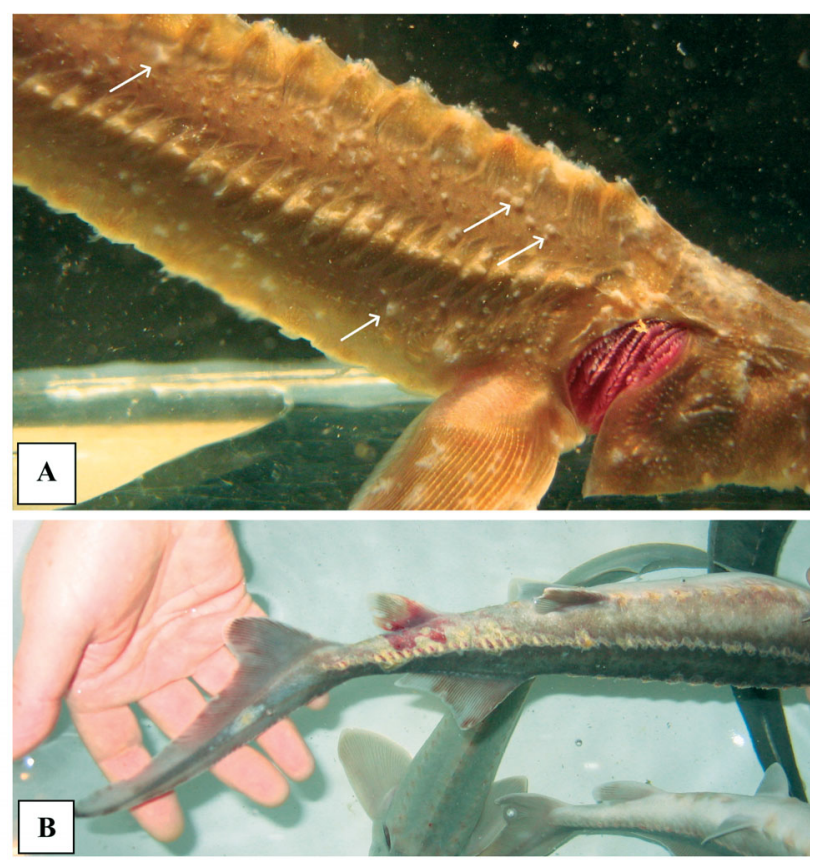

Fig. 4. Acipenser baeri. (A) Multiple plaques of epidermal proliferation (arrows) in a fingerling of Siberian sturgeon infected with Siberian sturgeon herpesvirus (SbSHV) and (B) haemorrhagic ulceration of the skin and the lateral scutes of the caudal trunk in virus-infected 2 yr old Siberian sturgeon faecal mucus-like contents of yellowish or bloody colour. The gall bladder was enlarged, and straw-yellow ascitic fluid (exudate) was present in the abdominal cavity of some diseased fish.

Compared to fingerlings, the infection process in $2 \mathrm{yr}$ old Siberian sturgeon was delayed and more extended resulting in $90 \%$ morbidity and $36.4 \%$ cumulative mortality only (Fig. 3). Following the appearance of lethargy and anorexia at about $14 \mathrm{dpi}$, the abovementioned alteration of the gill opercula movements was observed. While plaques of epidermal proliferation could be revealed in only few of the infected fish at about $25 \mathrm{dpi}$, most of the fish displayed extensive bloody ulceration of the lateral and ventral rows of scutes located predominantly on the caudal trunk (Fig. 4B). Also, petechial haemorrhages and small skin ulcers (3 to $8 \mathrm{~mm}$ ) appeared on different parts of the body. At the terminal stage of the disease, the ulcers became more numerous, began to fuse and acquired a yellowish colour, suggesting heavy myxobacterial contamination. The latter was further confirmed by light microscopy of the affected scute scrapings stained with $1 \%$ methylene blue. At $28 \mathrm{dpi}$, first mortality of fish with the above-mentioned clinical signs began. At necropsy, the liver of moribund fish was not white, as in fingerlings, but was marbled, with light brown-topink spots of different sizes. Haemorrhagic inflammation of the hind gut was common in most of the fish, and the heart looked knobby, flaccid and mottled. The swimbladder was enlarged, making the diseased fish float on the water surface. No mortality occurred in control fish.

The virus was re-isolated from gill, gill opercula, barbel, brain, liver, kidney, spleen, hind gut contents and abdominal exudate of experimentally infected and cohabited freshly dead or moribund Siberian sturgeon. However, the highest viral titres $\left(\geq 10^{9.1}\right.$ TCID $\left._{50} \mathrm{~g}^{-1}\right)$ were found in skin mucus, fin, skin and mouth tissues. These data provide evidence of integumentary tropism of the virus. Virus titres in the liver were also high (Table 1). SbSHV was also re-isolated from skin mucus, fin, gill operculum and mouth tissues but not from liver and heart of the last moribund $2 \mathrm{yr}$ old Siberian sturgeon at $56 \mathrm{dpi}$ and was not re-isolated from recovered fish at $73 \mathrm{dpi}$. After the water flow in the aquarium with the last moribund fingerling Siberian sturgeon was interrupted for $10 \mathrm{~h}$, the virus titre of the water reached $10^{3.85} \mathrm{TCID}_{50} \mathrm{ml}^{-1}$. In the flowthrough tank (7.5× water exchange a day) with ten $2 \mathrm{yr}$ old fish experiencing $90 \%$ morbidity approximately 1 mo post infection, the virus titre was $10^{2.85} \mathrm{TCID}_{50}$ $\mathrm{ml}^{-1}$ water.

The presence of virus in experimentally infected fish was further demonstrated by TEM. Ultrathin sections of hyperplastic epidermis plaques processed at the 
Table 1. Acipenser baeri. Virus titres in organs and tissues of moribund or freshly dead Siberian sturgeons following experimental immersion infection with Siberian sturgeon herpesvirus (SbSHV), determined by inoculation of SSO-2 cells. ND: not done; -: no virus was isolated after 2 to 3 'blind' passages

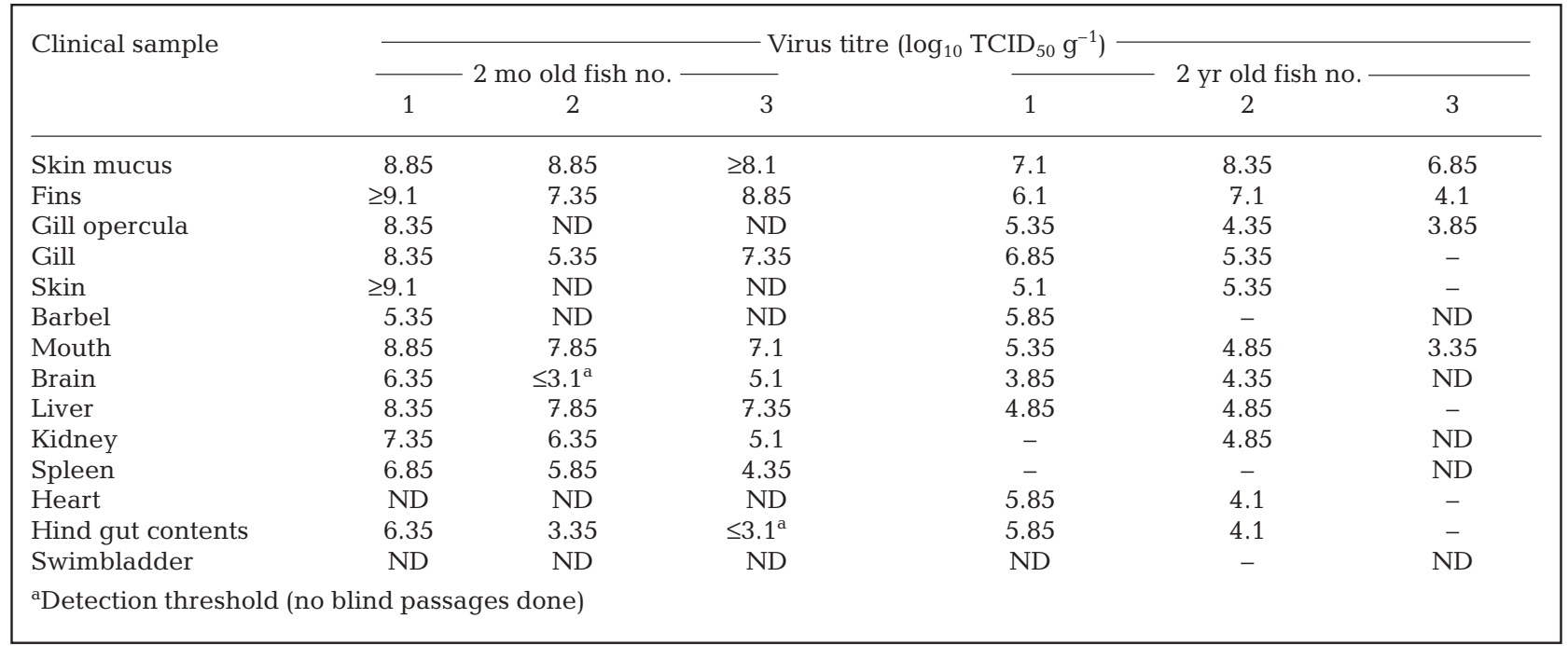

stage of their degeneration and sloughing revealed numerous enveloped virions scattered throughout intercellular space. Virus envelopes with short 'tail'like structures were quite common and sometimes abnormal virus particles containing 2 nucleocapsids within the same envelope could be observed (Fig. 5).

Experimental infections of carp and rainbow trout with SbSHV. The virus caused no disease in either carp fry or fingerlings of rainbow trout and was not reisolated from them. One Siberian sturgeon cohabited with carp fry died on Day 22 post cohabitation with haemorrhages on the abdomen, on the ventral part of the rostrum and around the mouth. No virus was isolated from fin and mouth tissues of that fish after 3 'blind' passages in SSO-2 cells at $15^{\circ} \mathrm{C}$. Other cohabited Siberian sturgeon fingerlings showed no evidence of disease.

\section{DISCUSSION}

In this study, we present data on isolation of a contagious virus, which is highly virulent to Siberian sturgeon. The Koch's-Rivers' postulates (Rivers 1937) were fulfilled, thus proving the viral etiology of the disease.

According to TEM data on virus anatomy and morphogenesis, the cause of the disease is thought to be a herpesvirus, although this must still be confirmed by additional methods such as nucleic acid sequencing. Icosahedral virus capsids were found to assemble and fill with nucleic acid in the cell nucleus, while mature virus particles with envelope and electron-dense tegument fixing the nucleocapsid inside it were numerous in the intercellular space. These features along with appropriate dimensions of the virions all suggest that the isolated agent is a herpesvirus.

Further data supporting this point of view include (1) the narrow species specificity of virus-susceptible cell cultures: only cell lines of sturgeon origin allow the virus replication; (2) the multinuclear syncytia formation in virus-infected cell cultures, and (3) high sensitivity of the virus to temperature, acid, alkali and lipid solvents (I. Shchelkunov \& T. Shchelkunova unpubl.). All of these properties are common to herpesviruses.

Herpesviruses are among the largest groups of viruses found in fish (Hedrick \& Sano 1989). A principal feature of disease pathogenesis attributed to many herpesviruses is their integumentary tropism. In fish, this includes both proliferative and inflammatory responses. Of 32 skin growths associated with fish viruses, 12 conditions (epidermal hyperplasia or papillomatosis) involved herpesviruses (Anders \& Yoshimizu 1994). Depending upon pathogenicity to their hosts, most fish herpesviruses can be tentatively divided into the following 4 subgroups:

(1) highly virulent viruses causing acute systemic infections and high mortality without specific involvement of the integument: channel catfish virus (CCV) (Fijan et al. 1970), black catfish Ictalurus melas herpesvirus (Alborali et al. 1996), goldfish haematopoietic necrosis virus (Jung \& Miyazaki 1995);

(2) weakly virulent viruses causing chronic systemic infections without specific involvement of the integument: Salmonid herpesvirus 1 (Eaton et al. 1989);

(3) highly virulent viruses causing or associated with acute diseases with high mortality and concomitant or postponed proliferative and necrotic or ulcerative in- 


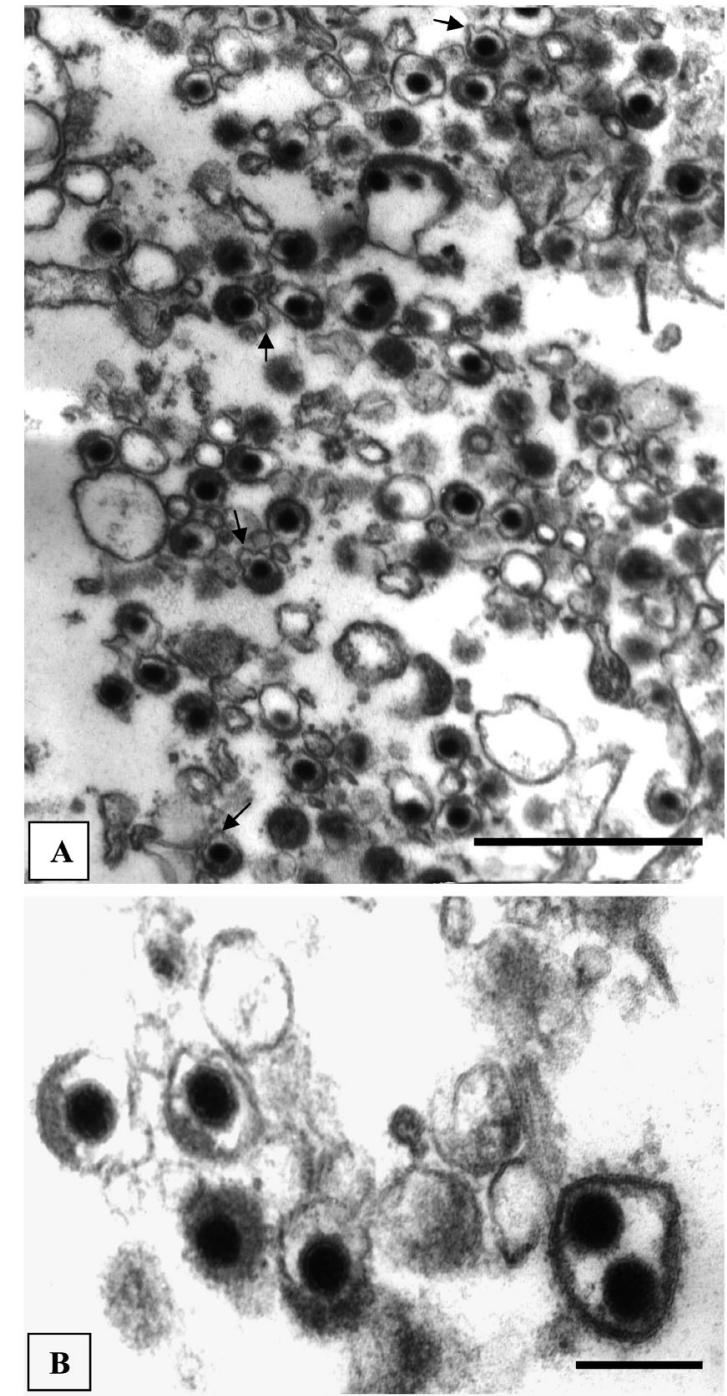

Fig. 5. Acipenser baeri. (A) Transmission electron micrographs of ultrathin section of a hyperplastic epidermis plaque at the stage of its degeneration and sloughing. Numerous herpesvirus particles scattered throughout intercellular space, with some of them 'tailed' (arrows). Scale bar $=1 \mu \mathrm{m}$. (B) Paired viral particles enveloped by the same membrane. Scale bar $=200 \mathrm{~nm}$

tegumentary lesions: white sturgeon Acipenser transmontanus herpesvirus 1 (Hedrick et al. 1991), white sturgeon herpesvirus 2 (Watson et al. 1995), Salmonid herpesvirus 2 (Kimura, Yoshimizu 1989), carp pox herpesvirus (Sano et al. 1990), koi herpesvirus (Hedrick et al. 2000), epizootic epitheliotropic disease virus of lake trout Salvelinus namaycush (Bradley et al. 1989, McAllister \& Herman 1989), herpesvirus of Japanese flounder Paralichthys olivaceus (Iida et al. 1989), herpesvirus of angelfish Pterophyllum altum (Mellergaard \& Bloch 1988), herpesvirus of blue-eyed plecostomus Panaque suttoni (Yanong 1995), and other viruses;
(4) weakly virulent viruses causing or associated with mild to benign conditions accompanied by the abovementioned integumentary manifestations: walleye Stizostedion vitreum vitreum diffuse epidermal hyperplasia herpesvirus (Kelly et al. 1983), spawning papillomatosis herpesvirus of European smelt Osmerus eperlanus (Anders \& Möller 1985), Atlantic salmon Salmo salar papillomatosis herpesvirus (Shchelkunov et al. 1992), northern pike Esox lucius herpesvirus (Yamamoto et al. 1984), sheatfish Silurus glanis herpesvirus (Békési et al. 1984), European eel Anguilla anguilla herpesvirus (Békési et al. 1986), Anguillid herpesvirus 1 (Hangalapura et al. 2007), and other viruses.

From the data presented above, Subgroups 3 and 4, characterised by development of integumentary lesions in virus-infected hosts, contain most of the fish herpesviruses. According to the provided criteria, the SbSHV aligns with Subgroup 3, which includes 2 type strains of sturgeon herpesviruses: the white sturgeon herpesviruses 1 and 2 (Acipenserid herpesviruses 1 and 2, AciHV-1 and AciHV-2).

Comparison of in vitro and in vivo properties of SbSHV (present study) to that of the 2 known white sturgeon herpesviruses (Hedrick et al. 1991, 2001, Watson et al. 1995) shows that SbSHV largely resembles AciHV-2. Indeed, in the inoculated WSSK-1 cell line, the SbSHV produced 'discrete, grape-like clusters of [infected] cells' similar to AciHV-2 but not polykariocytic 'globoid giant cells', which AciHV-1 produced (Watson et al. 1995). Upon gross examination of fingerlings and larger Siberian sturgeon infected with SbSHV, heavy epidermal hyperplasia, skin necrosis and ulceration of various localisation as well as gill pathology were the principal signs of disease, which were clear evidence for the integumentary tropism of the virus. Similar signs were observed in AciHV-2infected juvenile white sturgeon (Watson et al. 1995, Hedrick et al. 2001). This was further confirmed by high virus titres found in integumentary tissues for both AciHV-2 and SbSHV (Watson et al. 1995). In contrast to that, no signs of gross pathology were seen in AciHV-1-infected juveniles of white sturgeon, and only mild hyperplastic or necrotic lesions of epidermis were revealed by histopathology predominantly around the mucocutaneous junction (Hedrick et al. 1991). Contrary to AciHV-1, which caused only $35 \%$ cumulative mortality in bath immersion-infected white sturgeon fingerlings and could not be re-isolated from fish after 4 wk post infection, both AciHV-2 and SbSHV caused 80 and $100 \%$ mortality in fingerling fish of their hosts and were recovered from fingerling survivors at $70 \mathrm{dpi}$ and from moribund $2 \mathrm{yr}$ old fish at 56 dpi, respectively.

The similarity of properties of the SbSHV and AciHV-2 in vitro and in vivo suggests that these 2 
viruses may be related to each other. This could be best verified by comparison of PCR-amplified and sequenced key gene products of SbSHV to those of AciHV-2 and AciHV-1, and more generally, to those of other fish herpesviruses (Kurobe et al. 2008).

Surprisingly, despite a rather close similarity in properties of the 2 viruses, there is a striking difference between them in the response of the internal organs of virus-infected fish. In particular, the heavy pathology found upon gross examination in the liver, the heart and the hind gut of SbSHV-infected Siberian sturgeons (substantiated by comparatively high virus titres in these organs) is in contrast to the normal appearance of these organs (and lower virus titres in them) in AciHV2-infected white sturgeons (Watson et al. 1995). To clarify whether these differences might be due to differences between the viruses themselves or to different reactions of the different hosts, molecular comparison and experimental infections with the viruses using the same sturgeon species as hosts would be desirable.

The signs of disease caused by SbSHV have common traits with those found in herpesviral diseases of fishes other than sturgeon. Besides the integumentary lesions, other specific pathologies have been described in other herpesvirus-infected fishes including liver pathology. This has been observed in different fish species and varied from the 'liver dystrophy', as the only internal alteration found in the acutely diseased sheatfish (Békési et al. 1984), through anemic or pale but otherwise normal liver in diseased black catfish (Alborali et al. 1996), channel catfish (Fijan et al. 1970) and European eel (Haenen et al. 2002) to 'mottled' liver in rainbow trout Oncorhynchus mykiss with Salmonid herpesvirus 1 (Wolf \& Smith 1981), white spotted and even 'pearly white whole liver' in Pacific salmonids infected with Salmonid herpesvirus 2 (Kimura \& Yoshimizu 1989). The virus levels in affected liver usually corresponded to the degree of alteration found and was often the highest among internal organs. This, along with greater frequency of virus isolation from liver, indicated this organ as the principal target for Salmonid herpesviruses 1 and 2 (Ishigaki et al. 1987, Eaton et al. 1989, Kimura \& Yoshimizu 1989). We believe that regarding the internal organs, this is true for SbSHV as well.

The heart pathology was another marked pathology found in SbSHV-infected 2 yr old Siberian sturgeon. Although relevant data are scarce in the literature, various degrees of heart pathology have been described in other herpesvirus-infected fishes: from those recognisable only at the histopathological level - in rainbow trout, coho salmon Oncorhynchus kisutch and European eel (Wolf \& Smith 1981, Kumagai et al. 1995, Hangalapura et al. 2007) - to ones found both grossly (flaccid and mottled heart) and microscopically (degenerative cardiomyopathy and inflammatory response) - in carp Cyprinus carpio L. with koi herpesvirus (Haenen et al. 2004, Wada et al. 2004). More attention should be paid in the future to examination of the sturgeon heart, particularly in the age groups most susceptible to infection and disease.

Intestinal pathology has been found in fish infected with herpesviruses of all 4 of the above-mentioned subgroups, suggesting that it might be one of the marker signs of herpesvirus infection. This varied from microscopically observed alterations in European eel with Anguillid herpesvirus 1 (Hangalapura et al. 2007) to grossly recognisable catarrhal inflammation of the posterior intestine in CCV-infected channel catfish (Wolf et al. 1972) and rainbow trout with Salmonid herpesvirus 1 (Wolf \& Smith 1981), and haemorrhagic inflammation found in coho salmon having both natural or experimental infection with Salmonid herpesvirus 2 (Kumagai et al. 1994). The latter virus belongs to the same Subgroup 3 as the SbSHV. The heavy inflammatory alterations of the hind gut in SbSHV-infected fingerlings and 2 yr old Siberian sturgeon along with corresponding virus levels detected suggest that the intestine might be another important target for the virus.

Fin necrosis was one of the notable clinical signs in SbSHV-infected Siberian sturgeon. It was less prominent in older fish but could be clearly seen in infected fingerlings as a cloudy border, which appeared initially at the distal ends of the fins and extended proximally, causing fin disruption. This pathology was consistent with very high virus levels found in fin tissue. Signs of fin necrosis were described in fish infected with 2 other herpesviruses from the same Subgroup 3: epizootic epitheliotropic disease virus in lake trout (Bradley et al. 1989) and Salmonid herpesvirus 2 in coho salmon (Kumagai et al. 1994), although the virus levels in the affected fin tissue were not reported. Fins are usually underestimated as a site of virus replication in fish. However, high virus titres in fin tissue were not uncommon in fish infected with viruses, which lack clear integumentary tropism, such as the rhabdoviruses of spring viraemia of carp, viral haemorrhagic septicaemia and infectious haematopoietic necrosis (I. Shchelkunov \& T. Shchelkunova unpubl.).

Among the data indicating integumentary tropism of SbSHV, the most striking is the high virus titre in skin mucus of diseased Siberian sturgeon. This was among the highest found in different clinical samples from experimentally infected fingerlings and the highest in 2 yr old fish. In general, rather high virus titres can been found in skin mucus of fish with many other viruses, including the above-mentioned rhabdoviruses (I. Shchelkunov unpubl.) and is probably an efficient mechanism for releasing the mature virus into the 
environment. In addition, high virus levels in integumentary mucus make it a diagnostically valuable material for easy non-destructive sampling of fish for virological examination.

A change of disease pathogenesis pattern with ageing of fish was revealed in the present study. This was reflected in the shift of the disease manifestation from multiple plaques of proliferating epidermis and diffuse skin necrosis, which were common in SbSHV-infected fingerlings of Siberian sturgeon, to almost complete absence of the plaques and development of extensive, largely discrete, skin and scute ulceration in 2 yr old fish. These data are in agreement with the relevant findings in white sturgeon infected with WSHV-2 (Watson et al. 1995, Hedrick et al. 2001). The SbSHV replicated to a higher titre in fingerlings than in $2 \mathrm{yr}$ old fish, which is also true for other fish herpesviruses such as Salmonid herpesvirus 1 and CCV (Eaton et al. 1989). Similarly, changes of disease manifestation in fish within ageing from fry to subadults were reported for Salmonid herpesvirus 2 (Tanaka et al. 1984, Kumagai et al. 1994, Yoshimizu et al. 1995).

The virulence of SbSHV was very high: it caused $100 \%$ mortality in fry and fingerlings of Siberian sturgeon and about $40 \%$ mortality in 2 yr old fish both under fish farm and experimental conditions and was isolated from diseased bester fingerlings as well. The temperature between 14 and $17^{\circ} \mathrm{C}$ was used in the infection trials to imitate the natural temperature range at which the disease outbreaks usually occur in farmed sturgeon as well as to stick to the thermal optimum of the virus, which was found to be $15^{\circ} \mathrm{C}$ in vitro (I. Shchelkunov unpubl.). We also isolated and identified by neutralisation with an SbSHV-specific antiserum the same virus from outbreaks which occurred in 3 mo old Siberian sturgeon and 6 mo old Russian sturgeon $\times$ Siberian sturgeon hybrids in 2 different fish farms within the late summer and autumn of 2008, respectively. The virus susceptibility of other sturgeon species remains to be determined.

After exposure to the virus, carp fry and fingerlings of rainbow trout showed no signs of disease, and no virus was re-isolated from any of them. Only one cohabited Siberian sturgeon became sick and died from a cause other than the virus. Although the rest of cohabited fingerlings of Siberian sturgeon were not tested for SbSHV, we believe that, due to their very high susceptibility to the virus, these would have contracted the infection and showed overt disease should the virus have been excreted by the virus-exposed carp or rainbow trout. Fish herpesviruses are known for the narrow specificity in regard to their hosts. We found in a different study that all 7 acipenserid and none of the 9 other cell lines tested (of cyprinid, salmonid, centrarchid and cichlid origin) were suscep- tible to SbSHV (I. Shchelkunov et al. unpubl.). Taken together, these data suggest that carp and rainbow trout are not susceptible to the virus and are unable to transmit the infection to susceptible fish.

By TEM, mature virions of SbSHV with a short 'tail'like structure of the envelope were observed in the intercellular space. Similar 'tailed' virions have been found in AciHV-2 and other fish herpesviruses (Watson et al. 1995). Nearly opposite to the empty virion 'tail', the most darkly stained tegument proteins were concentrated within the envelope. These are associated with herpesvirus capsids and assist final envelopment during viral budding into exocytotic vesicles or through the outer cell membrane (Fields \& Knipe 1986, Wagner \& Hewlett 2004). Similar to many other herpesviruses, mature virions of SbSHV are not tegumented in full, thus demonstrating that full tegumention is not essential for maturation of at least some herpesviruses.

Besides SbSHV, paired (or olygonucleocapsid) virions have also been found in the herpesvirus of angelfish Pterophyllum altum (Mellergaard \& Bloch 1988). These are not unique for herpesviruses but have been also described as abnormal virus forms in other enveloped viruses such as orthomyxoviruses, togaviruses, rhabdoviruses, retroviruses and others (Zhdanov 1975, Bykovsky 1983).

Upon gross examination, the disease appears as a prominent necro-haemorrhagic syndrome complicated by secondary opportunistic infections (saprolegniosis and myxobacteriosis). Despite the fact that the signs of the syndrome are rather indicative, these cannot be considered pathognomonic for the disease. This is particularly true for skin haemorrhages, which, according to our observations, can be the only gross pathological sign found in Siberian sturgeon younger than 2 mo old and infected with SbSHV. While the SbSHV can be readily isolated from clinically diseased fish, we have recovered opportunistic bacteria only and no viruses from haemorrhagic fingerlings of Siberian sturgeon originated from some fish farms with water temperature permissive for the virus infection. This was also true for white sturgeon with skin haemorrhagies (Hedrick et al. 2001).

Although the virus infects different organs and tissues of sturgeon, it clearly shows integumentary tropism. Affected fish excrete the virus in skin mucus, slimy pseudo-faecal excretions from the anus and probably through the gills and with urine. It can be speculated that the cause of fish death might be osmotic shock, due to extensive damage of integumentary tissues, accompanied by gill, liver, intestine and heart failure.

To our knowledge, this is the first case of sturgeonspecific virus isolation from non-American sturgeon 
species. This is also the first viral disease of sturgeons that has been diagnosed in Russia. The source of infection in the hatchery in Tver Province is unknown. The virus either originally circulated in the local watershed or may have been introduced from other regions of the country with live sturgeons being delivered to the hatchery to form the spawner stock. Watson et al. (1995) isolated AciHV-2 from gonad tissues of adult broodstock of white sturgeon, thus demonstrating that sturgeon herpesviruses can persist at fish farms. For many years, the hatchery in Tver Province has been producing and distributing fertilised sturgeon eggs within both Russia and abroad, and this practice might promote worldwide spread of the infection.

Acknowledgements. We thank Prof. R. P. Hedrick for his interest in this work, critical reading of the manuscript and valuable suggestions. Special thanks also to A. V. Rekubratsky, N. F. Shmakov and V. N. Dementyev, who provided fish of different species for testing virus pathogenicity.

Note added in proof. Since the time this manuscript was accepted for publication, the close genetic relationship of SbSHV to herpesvirus isolates of North American sturgeons has been shown (R. P. Hedrick pers. comm.). These data are to be included in a different manuscript, which is currently in preparation.

\section{LITERATURE CITED}

Adkison MA, Cambre M, Hedrick RP (1998) Identification of an iridovirus in Russian sturgeon (Acipenser gueldenstaedti) from northern Europe. Bull Eur Assoc Fish Pathol $18: 29-32$

Alborali L, Bovo G, Lavazza A, Capellaro H, Guadagnini PF (1996) Isolation of a herpesvirus in breeding catfish (Ictalurus melas). Bull Eur Assoc Fish Pathol 16:134-137

Anders K, Möller H (1985) Spawning papillomatosis of smelt, Osmerus eperlanus L., from the Elbe estuary. J Fish Dis 8: 233-235

Anders K, Yoshimizu M (1994) Role of viruses in induction of skin tumors and tumor-like proliferations of fish. Dis Aquat Org 19:215-232

Békési L, Kovacs-Gayer E, Ratz F, Turkovics O (1984) Skin infection of the sheatfish (Silurus glanis L.) caused by a herpesvirus. Symp Biol Hung 23:25-30

Bradley TM, Medina DJ, Chang PW, McClain J (1989) Epizootic epitheliotropic disease of lake trout (Salvelinus namaycush): history and viral etiology. Dis Aquat Org 7: 195-201

Bykovsky AP (ed) (1983) Oncogenic viruses (Atlas). Meditsina, Moscow (in Russian)

Davison AJ, Eberle R, Ehlers B, Hayward GS and others (2009) The order Herpesvirales. Arch Virol 154:171-177

Eaton WD, Wingfield WH, Hedrick RP (1989) Prevalence and experimental transmission of the steelhead herpesvirus in salmonid fishes. Dis Aquat Org 7:23-30

Fields BN, Knipe DM (eds) (1986) Fundamental virology. Raven Press Book, New York

Fijan NN, Wellborn TL, Naftel JP (1970) An acute viral disease of channel catfish. US Fish Wildl Serv Tech Pap $43: 1-11$
Georgiadis MP, Hedrick RP, Carpenter TE, Gardner IA (2001) Factors influencing transmission, onset and severity of outbreaks due to white sturgeon iridovirus in a commercial hatchery. Aquaculture 194:21-35

Haenen OLM, Dijkstra SG, van Tulden PW, Davidse A, van Nieuwstadt AP, Wagenaar F, Wellenberg GJ (2002) Herpesvirus anguillae (HVA) isolations from disease outbreaks in cultured European eel Anguilla anguilla in the Netherlands since 1996. Bull Eur Assoc Fish Pathol 22: $247-257$

Haenen OLM, Way K, Bergmann SM, Ariel E (2004) The emergence of koi herpesvirus and its significance to European aquaculture. Bull Eur Assoc Fish Pathol 24: 293-307

Hangalapura BN, Zwart R, Engelsma MY, Haenen OLM (2007) Pathogenesis of Herpesvirus anguilla (HVA) in juvenile European eel Anguilla anguilla after infection by bath immersion. Dis Aquat Org 78:13-22

Hedrick RP, Sano T (1989) Herpesviruses of fish. In: Ahne W, Kurstak E (eds) Viruses of lover vertebrates. SpringerVerlag, Berlin, p 161-170

> Hedrick RP, McDowell TS, Groff JM, Yun S, Wingfield WH (1991) Isolation of an epitheliotropic herpesvirus from white sturgeon Acipenser transmontanus. Dis Aquat Org 11:49-56

Hedrick RP, Gilad O, Yun S, Spangenberg JN and others (2000) A herpesvirus associated with mass mortality of juvenile and adult koi, a strain of a common carp. J Aquat Anim Health 12:44-57

Hedrick RP, LaPatra S, McDowell T, MacConnell B (2001) A workshop on sturgeon diseases. 4th Int Symp Sturgeon. Wisconsin Department of Natural Resources, Oshkosh, WI

Iida Y, Masumura K, Nakai T, Sorimachi M, Matsuda H (1989) A viral disease in larvae and juveniles of the Japanese flounder Paralichthys olivaceus. J Aquat Anim Health 1: 7-12

Ishigaki K, Kodama H, Hayashi Y, Mikami T, Izawa H, Suzuki S, Saneyoshi M (1987) Pathological characteristics of salmonid herpesviruses and antibody production of the virus-infected fish. Jpn J Vet Sci 49:403-410

Ito S, Karnovsky MJ (1968) Formaldehyde-glutaraldehyde fixatives containing trinitrocompounds. J Cell Biol 39: 168A-169A

Jung SJ, Miyazaki T (1995) Herpesviral haematopoietic necrosis of goldfish, Carassius auratus (L.). J Fish Dis 18: 211-220

Kazarnikova AV (2007) Diseases of sturgeons in recirculated water systems. Veterinaria (Mosc) 3:25-29 (in Russian)

Kelley GO, Waltzek TB, McDowell TS, Yun SC, LaPatra SE, Hedrick RP (2005) Genetic relationships among herpeslike viruses isolated from sturgeon. J Aquat Anim Health 17:297-303

Kelly RK, Nielsen O, Mitchell SC, Yamamoto T (1983) Characterization of Herpesvirus vitreum isolated from hyperplastic epidermal tissue of walleye, Stizostedion vitreum vitreum (Mitchill). J Fish Dis 6:249-260

Kimura T, Yoshimizu M (1989) Salmonid herpesvirus: OMV, Oncorhynchus masou virus. In: Ahne W, Kurstak E (eds) Viruses of lower vertebrates. Springer-Verlag, Berlin, p 171-183

Kumagai A, Takahashi K, Fukuda H (1994) Epizootics caused by salmonid herpesvirus type 2 infection in maricultured coho salmon. Fish Pathol 29:127-134

Kumagai A, Horie N, Sato Y, Takahashi K, Sano T, Fukuda H (1995) Application of fluorescent antibody technique on diagnosis of salmonid herpesvirus 2 infection in maricultured coho salmon. Fish Pathol 30:59-65 
Kurobe T, Kelley GO, Waltzek TB, Hedrick RP (2008) Revised phylogenetic relationships among herpesviruses isolated from sturgeons. J Aquat Anim Health 20:96-102

LaPatra SE, Hogans B, Groman D, Groff JM (2001) Detection of a herpesvirus associated with disease in cultured shortnose sturgeon, Acipenser brevirostrum, on the Atlantic coast of Canada. 4th Int Symp Sturgeon. Abstract book. Wisconsin Department of Natural Resources, Oshkosh, WI

McAllister PE, Herman RL (1989) Epizootic mortality in hatchery-reared lake trout Salvelinus namaycush caused by a putative virus possibly of the herpesvirus group. Dis Aquat Org 6:113-119

Mellergaard S, Bloch B (1988) Herpesvirus-like particles in angelfish Pterophyllum altum. Dis Aquat Org 5:151-155

Morgan JF, Morton HJ, Parker RC (1950) The nutrition of animal cells in tissue culture. I. Initial studies on a synthetic medium. Proc Soc Exp Biol Med 73:1-8

Raverty S, Hedrick RP, Henry J, Saksida S (2003) Diagnosis of sturgeon iridovirus infection in farmed white sturgeon in British Columbia. Can Vet J 44:327-328

Reed LJ, Muench H (1938) A simple method of estimating fifty percent endpoints. Am J Hyg 27:493-497

Reynolds ES (1963) The use of lead citrate at high pH as an electron-opaque stain in electron microscopy. J Cell Biol $17: 208-212$

Rivers T (1937) Viruses and Koch's postulates. J Bacteriol 33: $1-12$

Sano T, Morita N, Shima N, Akimoto M (1990) A preliminary report on pathogenicity and oncogenicity of cyprinid herpesvirus. Bull Eur Assoc Fish Pathol 10:11-13

Shchelkunov IS, Karaseva TA, Kadoshnikov YP (1992) Atlantic salmon papillomatosis: visualization of herpesvirus-like particles in skin growths of affected fish. Bull Eur Assoc Fish Pathol 12:28-31

Shchelkunova TI, Kolbassova YP, Shchelkunov IS (2006) Fish virus susceptibility of continuous cell lines established from Siberian sturgeon tissues. Tsitologiya 48:814-815 (in Russian)

Editorial responsibility: Mark Crane, Geelong, Victoria, Australia
Tanaka M, Yoshimizu M, Kimura T (1984) Oncorhynchus masou virus: pathological changes in masu salmon (Oncorhynchus masou), chum salmon (O. keta) and coho salmon (O. kisutch) fry infected with OMV by immersion method. Bull Jpn Soc Sci Fish 50:431-437

Wada S, Kurata O, Hatai K, Yuasa K (2004) Histopathological changes in carp naturally infected with koi herpesvirus (KHV). In: Takai R (ed) KHV infection: present status and future prospects for prevention. Tokyo University of Marine Science and Technology, Tokyo, p 27-28

Wagner EK, Hewlett MJ (2004) Basic virology, 2nd edn. Blackwell Publishing, Malden, MA

Waltzek TB, Kelley GO, Davison AJ, Hedrick RP (2006) Evolutionary relationships of the fish and amphibian herpesviruses. In: 5th Int Symp Aquat Anim Health. Program and Abstracts. Health Section, American Fisheries Society, San Francisco, CA

Watson LR, Yun SC, Groff JM, Hedrick RP (1995) Characteristics and pathogenicity of a novel herpesvirus isolated from adult and subadult white sturgeon Acipenser transmontanus. Dis Aquat Org 22:199-210

> Wolf K, Smith CE (1981) Herpesvirus salmonis: pathological changes in parenterally-infected rainbow trout, Salmo gairdneri Richardson, fry. J Fish Dis 4:445-457

Wolf K, Herman RL, Carlson CP (1972) Fish viruses: changes associated with experimental channel catfish virus disease. J Fish Res Board Can 29:149-150

Yamamoto T, Kelly RK, Nielsen O (1984) Epidermal hyperplasias of northern pike (Esox lucius) associated with herpesvirus and C-type particles. Arch Virol 79:255-272

Yanong RPE (1995) Possible herpesvirus-associated disease in the blue-eyed plecostomus, Panaque suttoni. IAAAM Proc 26:83

> Yoshimizu M, Fukuda H, Sano T, Kimura T (1995) Salmonid herpesvirus 2. Epizootiology and serological relationship. Vet Res 26:486-492

Zhdanov VM (ed) (1975) Atlas of virus cytopathology. Meditsina, Moscow (in Russian)

Submitted: June 30, 2008; Accepted: August 4, 2009

Proofs received from author(s): October 10, 2009 